\title{
FUNDAMENTALISME AGAMA
}

\author{
Nur Rosidah \\ IAIN Walisongo Semarang \\ e-mail: nur_rosy@yahoo.com
}

\begin{abstract}
Al-Qur'an frequently stated as a basic source for violence and terror as well as Islamic fundamentalism. This is because materially there are some provocativeagitative verses in al-Qur'an for violence doer and terrorist. This article discussed about the way to study Qur'an verses on violence and the interpretation methodology applied to understanding that verses.

$* * *$

Al-Qur'an seringkali dinyatakan sebagai landasar perilaku kekerasan dan teror serta fundamentalisme Islam. Hal ini karena secara material terdapat beberapa ayat di dalam al-Qur'an yang provokatif dan agitatif untuk terjadinya kekerasan dan teror. Artikel ini membahas tentang cara melakukan kajian ayat-ayat alQur'an tentang kekerasan dan metode interpretasi yang diterapkan untuk memahami ayat tersebut.
\end{abstract}

Keywords: al-Qur'an, interpretasi, kekerasan, fundamentalisme 


\section{A. Pendahuluan}

Fundamentalisme agama kembali menjadi isu penting pasca terjadinya penembakan dan penangkapan terhadap "aktivis-aktivis" Muslim serta penemuan senjata dan bahan peledak di wilayah-wilayah basis para "aktivis" tersebut beberapa waktu yang lalu. Peristiwa-peristiwa tersebut memunculkan kembali wacana fundamentalisme agama yang sempat meredup setelah mulai terlupakannya aksi terorisme di gedung World Trade Center (WTC), Amerika Serikat, pada 11 September 2001 yang menewaskan hampir tiga ribu orang tersebut. Dalam konteks keindonesiaan, isu fundamentalisme agama menjadi lebih menghangat setelah terjadinya kasus bom Bali yang menewaskan 180 orang, yang sebagian besar adalah warga negara asing.

Fundamentalisme agama memang seringkali dikaitkan dengan tindakantindakan kekerasan dan terorisme. Secara historis, terma fundamentalisme ${ }^{1}$ agama mulanya digunakan untuk menyebut gerakan dalam agama Kristen Protestan di Amerika Serikat yang lahir dalam situasi konflik antara budaya urban dan budaya pedesaan pasca Perang Dunia I, di mana terjadi depresi nilainilai agraris dalam proses industrialisasi dan urbanisasi di negeri itu. ${ }^{2}$ Gerakan ini menganut ajaran ortodoksi Kristen yang berdasarkan atas keyakinankeyakinan mendasar tertentu. Keyakinan dimaksud adalah bahwa kitab suci secara harfiah tidak mengandung kesalahan (the literal inerrancy of the scriptures), Yesus akan turun kembali ke dunia (the second coming of Yesus Christ), Yesus terlahir dari Maria yang perawan (the virgin birth), Yesus dibangkitkan secara jasmaniah dari kematian (the physical resurrection of the body), Yesus menebus dosa seluruh umat manusia (the substitution atonement), manusia pada dasarnya sangat buruk, ada dalam keadaan berdosa semenjak awal kejadiannya (the total depravity of man- original sin). ${ }^{3}$

Keyakinan-keyakinan dasar di atas sebenarnya tidak sedikitpun menyiratkan kemestian munculnya sikap kaku tanpa kompromi sebagaimana yang dibayangkan pada sekte-sekte yang saat ini diidentifikasi sebagai fundamen-

\footnotetext{
1 Fundamental merupakan kata sifat yang memberikan pengertian "bersifat dasar (pokok), mendasar". Kata tersebut diderivasi dari kata "fundament" yang berarti "dasar, asas, alas, fondasi". Lihat Poerwadarminta, Kamus Besar Bahasa Indonesia, (Jakarta: Balai Pustaka, 1990), h. 245.

2Lihat M. Dawam Rahardjo, "Fundamentalisme" dalam Muhammad Wahyuni Nafis (Ed.), Rekonstruksi dan Renungan Religius Islam, (Jakarta: Paramadina, 1996), h. 87.

3 Harry Mc Mullan, "Understanding Christian Fundamentalism" dalam http://www. ubfellowship.org/archive/readers/doc176.htm.
} 
talis. Pada mulanya ajaran-ajaran tersebut memang memberikan ruang bagi pertimbangan nalar untuk mengkritisinya secara cerdas. Penganut ajaran tersebut dapat mengkritisi dan memperdebatkan keyakinan-keyakinan dasar ini. Namun perkembangan selanjutnya kemudian menunjukkan fenomena yang berbalik. Keyakinan-keyakinan dasar tersebut kemudian diyakini sedemikian rupa sehingga hanya memberikan sedikit ruang yang sempit bagi munculnya pendapat yang berbeda. Pembalikan fenomena tersebut dapat dilihat pada, misalnya, ajaran bahwa Bibel tidak mengandung kesalahan kemudian dikembangkan menjadi ajaran bahwa kitab tersebut menjadi satu-satunya sumber kebenaran. ${ }^{4}$ Pengembangan keyakinan tersebut tentu melahirkan sikap kaku tanpa mengenal kompromi dan cenderung mengarah pada klaimklaim kebenaran (truth claims). Klaim-klaim kebenaran tersebut pada gilirannya dapat melahirkan pembenaran penggunaan kekerasan bagi elemenelemen lain yang tidak sejalan dengannya.

Dengan kerangka berpikir seperti itu, tentu menjadi mudah untuk mengidentifikasi munculnya fenomena fundamentalisme dalam setiap agama. Fundamentalisme agama merupakan fenomena yang dapat ditemukan kemunculannya dalam setiap agama, termasuk di antaranya juga Islam.

Secara historis, fenomena fundamentalisme Islam bisa dirunut dalam rentang sejarah yang sedemikian panjang hingga pada era awal perkembangan agama Muhammad tersebut. Upaya-upaya pembunuhan yang didalangi oleh sekte Khawarij terhadap tokoh-tokoh sahabat Nabi seperti Ali bin Abi Thalib, Mu'awiyah dan Amr bin Ash sebagai rangkaian lanjutan dari peristiwa tahkim merupakan cikal-bakal kelahiran gerakan-gerakan fundamentalisme Islam. Argumentasi yang dijadikan pembenar sekte Khawarij atas tindakan-tindakan kekerasan mereka juga berlatar belakang keagamaan, yaitu bahwa mereka yang dijadikan korban adalah tokoh-tokoh yang melegalkan tahkìm yang menurut mereka haram untuk dilakukan. Padahal, menurut mereka, umat Islam harus menyelesaikan persoalan-persoalan mereka dengan didasarkan pada alQur'an sebagai satu-satunya sumber kebenaran.

Sejarah juga mentranskrip rekaman-rekaman historis tentang fenomena munculnya gerakan fundamentalisme Islam pada peristiwa Mihnah pada masa pemerintahan khalifah al-Ma'mun (813-833). Dalam peristiwa tersebut,

${ }^{4}$ Ibid. 
terjadi pemaksaan pendapat oleh sekte Mu'tazilah, sebuah sekte dalam Islam yang justru mendaku dirinya sebagai sekte rasionalis. Tokoh-tokoh Islam dan pemuka masyarakat yang tidak sependapat dengan sekte tersebut dipenjarakan, disiksa dan bahkan ada yang dihukum mati.

Fenomena munculnya gerakan-gerakan fundamentalisme Islam hampir tidak pernah berhenti dalam rentang perjalanan sejarah umat Islam. Fenomena tersebut tetap berlanjut hingga kini dengan modus-modus yang lebih beragam. Pemboman terhadap World Trade Center (WTC), Amerika Serikat, pada 11 September 2001, pemboman pusat hiburan di Legian Bali, pembajakan-pembajakan terhadap pesawat milik negara-negara barat dan lain-lain merupakan rangkaian lanjutan sejarah kemunculan fundamentalisme Islam.

Dari rekaman sejarah tersebut bisa dilihat bahwa fundamentalisme Islam lebih banyak menekankan — atau setidak-tidaknya membenarkan-penggunaan kekerasan atas nama agama. Islam dianggap mengajarkan pada para pemeluknya yang fanatik untuk melakukan tindakan kekerasan tersebut sebagai manifestasi dari keimanan. Dalam pembicaraan mengenai sekte ini, orang kemudian membayangkan adanya sekelompok orang beriman yang meyakini-mungkin secara salah-bahwa Tuhan telah menyuruhnya untuk melakukan apa saja yang mungkin dapat dilakukan untuk membela agama-Nya. ${ }^{5}$

Fundamentalisme Islam, sebagaimana juga fundamentalisme dalam agama lain, memiliki beberapa karakteristik yang membedakannya dengan sekte lain. Pertama, skripturalisme, yaitu keyakinan harfiah terhadap kitab suci yang merupakan firman Tuhan dan dianggap tidak mengandung kesalahan. ${ }^{6}$ Kedua, penolakan terhadap hermeneutika. Teks al-Qur'an dalam pandangan sekte ini harus dipahami secara literal sebagaimana bunyinya. Nalar dipandang tidak mampu memberikan interpretasi yang tepat terhadap teks, bahkan terhadap teks-teks yang satu sama lain bertentangan sekalipun. Ketiga, penolakan terhadap pluralisme dan relativisme yang dianggap merongrong kesucian teks. Keempat, penolakan terhadap perkembangan his-

\footnotetext{
${ }^{5}$ Machasin, "Fundamentalisme dan Terorisme," makalah yang dipresentasikan dalam Moslem Scholars Congress dengan tema "Reading of The Religious Texts and The Roots of Fundamentalism," Saphir Yogyakarta, Minggu, 13 Juni 2004

${ }^{6}$ Richard C. Antoun, Memahami Fundamentalisme, terj. M. Shodiq, (Surabaya: Pustaka Eureka, 2003), h. 41.
} 
toris dan sosiologis yang dianggap membawa manusia semakin jauh melenceng dari doktrin literal kitab suci. ${ }^{7}$

Aksi-aksi kekerasan dan terorisme sebagai cara mengekspresikan pemahaman fundamentalisme Islam tersebut senantiasa dikaitkan dengan alQur'an. Hal ini karena secara tekstual banyak ayat-ayat al-Qur'an yang memberikan ruang atau bahkan memotivasi lahirnya gerakan fundamentalisme Islam tersebut. Dengan kata lain, aksi-aksi kekerasan dan terorisme yang dilakukan oleh sekte Islam fundamentalis tersebut memiliki "dasar Qur'ani”. "Dasar Qur'ani” tersebut bisa dilacak dalam beberapa ayat al-Qur'an. Misalnya:

“Tidaklah pantas seorang mukmin, laki-laki ataupun perempuan, mengambil pilihannya sendiri untuk perkaranya ketika Allah dan Rasul-Nya telah menetapkan suatu perkara (perintah). Dan barang siapa durhaka pada Allah maka sesungguhnya dia telah sesat dengan kesesatan yang jelas." 8

Pemahaman secara tekstual terhadap ayat tersebut hanya memberikan satu alternatif bahwa perintah apapun yang diberikan oleh Allah dan RasulNya harus dilaksanakan tanpa harus melihat dalam konteks apa perintah tersebut diberikan. Pemahaman secara tekstual terhadap ayat tersebut juga tidak tidak memberikan pengecualian terhadap perintah-perintah yang, misalnya, menyangkut hubungan antara umat Islam dengan pemeluk agama lain.

Dalam hal ini, ada beberapa ayat al-Qur'an yang secara tekstual memerintahkan untuk memerangi pemeluk agama lain, misalnya:

"Kemudian apabila telah habis bulan-bulan yang dihormati itu maka bunuhlah orang-orang musyrik itu di mana saja kamu menemuinya, tawanlah mereka, kepunglah mereka, dan awasilah mereka di tiap-tiap tempat pengintaian. Kemudian jika mereka bertobat dan mendirikan shalat serta memberi zakat, maka lepaskanlah mereka. Sesungguhnya Allah Maha Pengampun, Maha Mengasihi."

Selain itu, ayat yang lain juga menyatakan:

"Perangilah orang-orang yang tidak beriman kepada Allah dan hari akhir, tidak mengharamkan apa yang telah diharamkan oleh Allah dan Rasul-

${ }^{7}$ Lihat Azyumardi Azra, "Fenomena Fundamentalisme dalam Islam,” dalam Ulumul Qur'an No. 3, Vol. IV, tahun 1993, h. 18-19.

${ }^{8}$ QS. al-Ahzab [33]: 36.

${ }^{9}$ QS. al-Taubah [9]: 5 . 
Nya, dan tidak memeluk agama yang benar, yaitu orang dari orang-orang yang diberi kitab, sampai mereka membayar jizyah dengan patuh, sedang mereka dalam keadaan tunduk."10

Pemahaman secara tekstual terhadap ayat-ayat tersebut hanya memberikan satu pilihan bahwa umat Islam harus memerangi pemeluk agama lain, juga terhadap umat Islam yang tidak secara "total"11 melaksanakan ajaran-ajaran Islam. Ayat tersebut juga tidak menjelaskan apakah perintah untuk menyerang pemeluk agama lain tersebut diberikan dalam konteks masa perang atau masa damai. Sehingga dalam situasi apapun, berdasarkan pemahaman tekstual ayat-ayat tersebut, apabila umat Islam menemukan pemeluk agama lain maka mereka wajib untuk menyerangnya. Pemahaman tersebut mendapatkan penguatan dari QS. al-Anfal [8]: 61,

"Jika mereka condong pada perdamaian, maka hendaklah kamu condong kepadanya."

Ayat tersebut dipahami oleh kelompok fundamentalis Islam bahwa umat Islam tidak boleh mengambil inisiatif untuk terciptanya perdamaian dengan pemeluk agama lain. Umat Islam hanya boleh berdamai dengan non Muslim kalau mereka yang lebih dulu mengambil inisiatif menciptakan perdamaian.

Pembacaan secara parsial-tekstual terhadap ayat-ayat al-Qur'an tersebut akan menghasilkan pemahaman bahwa dalam al-Qur'an memang terdapat teologi kekerasan, yang mengajarkan umat Islam untuk menyerang pemeluk agama lain. Dengan kata lain, ada pembenaran-pembenaran atau justifikasi bagi munculnya aksi-aksi kekerasan berbasis agama. Hal ini tentu berbenturan dengan klaim-klaim yang biasa dimunculkan bahwa Islam merupakan agama yang cinta damai dan membawa berkah bagi seru sekalian alam (raḥmatan li 'l-'âlamīn). Pembenaran-pembenaran kekerasan tersebut juga kontra produktif dengan wacana pluralisme agama yang banyak dikembangkan oleh sarjana-sarjana Muslim, yang tentu juga memiliki landasan

${ }^{10}$ QS. al-Taubah [9]: 29.

11 Totalitas ketaatan seorang muslim pada keseluruhan perintah dan larangan agama dianggap sebagai prasyarat bagi terwujudnya kejayaan umat Islam. Sekte fundamentalis Islam percaya bahwa keterpinggiran dan ketidakberdayaan umat Islam dalam percaturan internasional karena mereka meninggalkan ajaran-ajaran Islam. Lihat Machasin, "Fundamentalisme dan Terorisme," h. 12. 
teologis dalam al-Qur'an. ${ }^{12}$ Atas dasar inilah penulis merasa tertarik untuk mengkaji akar-akar kekerasan berbasis agama sebagai akibat pemahaman yang "fundamental" terhadap ayat-ayat al-Qur'an.

\section{B. Diskursus Fundamentalisme}

Meski diyakini bahwa secara harfiah tidak mengandung kesalahan (the literal inerrancy of the scriptures), setiap kitab suci selalu memiliki latar belakang sejarahnya sendiri. Ada latar sosial-politik dan budaya yang membentuk karakter dari setiap kitab suci, termasuk al-Qur'an.

Berbeda dengan kitab-kitab suci lainnya yang turun dalam "satu paket" sekaligus, al-Qur'an turun di Semenanjung Arabia dalam rentang waktu yang cukup lama, yaitu 22 tahun, 2 bulan dan 22 hari. Dalam rentang waktu yang sedemikian lama tersebut, situasi sosial-politik seringkali tidak menentu. Ada saat-saat di mana situasi sosial-politik yang terjadi di Semenanjung Arabia menjadi begitu kondusif, sehingga ayat-ayat al-Qur'an yang turun pada saat itu memiliki karakter teduh dan apresiatif terhadap munculnya beragam perbedaan. Namun ada saat-saat di mana situasi sosial-politik menjadi tidak menentu yang menandai adanya ketegangan hubungan umat Islam dengan komunitas non-Muslim, sehingga ayat-ayat al-Qur'an yang turun pada saat itu cenderung provokatif-agitatif, kaku, keras dan cenderung menolak adanya perbedaan. ${ }^{13}$

Dalam upaya memahami perbedaan watak dan karakteristik ayat-ayat al-Qur'an, ayat-ayat al-Qur'an tersebut tidak bisa dipahami secara parsial atau sepotong-potong dan terpisah. Al-Qur'an sebagai teks yang utuh harus dipahami secara holistik-komprehensif. Dengan cara itulah maka akan tampak watak dan karakter al-Qur'an yang sebenarnya, yaitu pembawa kedamaian dan rahmat bagi seluruh umat manusia (rahmatan li 'l-ấlaminn). ${ }^{14}$ Dengan kata lain, al-Qur'an tidak bisa dijadikan sebagai pijakan bagi tindakan-

\footnotetext{
12 Pluralisme agama juga memiliki landasan teologis dalam al-Qur'an, misalnya QS. al-Hajj : 40 yang mendorong umat Islam untuk senantiasa menghormati pemeluk agama lain, QS. al-Baqarah [2]: 256 yang menyatakan bahwa tidak ada paksaan dalam beragama, dan QS. al-An'am [6]: 108 yang melarang umat Islam untuk mencerca pemeluk agama lain.

${ }^{13}$ Akhmad Arif Junaidi, “Memahami Karakteristik al-Qur'an,” makalah diskusi Dosen Fakultas Syariah IAIN Walisongo, tanggal 27 April 2005.

${ }^{14}$ Ibid.
} 
tindakan kekerasan atas nama agama yang mengandalkan semangat fundamentalisme.

Adalah Hassan Hanafi, seorang intelektual Muslim kelahiran Mesir, yang banyak melahirkan gagasan-gagasan cerdas tentang fundamentalisme Islam. Dalam tulisannya, Hassan Hanafi banyak mengupas gerakan-gerakan fundamentalisme Islam di Mesir yang banyak melibatkan beberapa organisasi militan di negara Islam tersebut. Dalam pandangan Hanafi, fundamentalisme Islam bukanlah gerakan ekstremisme atau eksklusivisme, juga bukan gerakan bawah tanah sebagaimana dilakukan oleh beberapa organisasi militan seperti al-Ikhwan al-Muslimun dan Jama'ah al-Jihad. Fundamentalisme Islam bukanlah ortodoksi, romantisme sejarah, ataupun sikap apriori terhadap modernitas. Fundamentalisme Islam, dalam pandangan Hanafi, merupakan gerakan yang memiliki visi dan misi pembentukan manusia seutuhnya agar mampu berperan menggalang persatuan dan menjaga identitas umat, dan membela kelompok-kelompok lemah yang terpinggirkan. Ia tidak hanya berkutat pada seruan mendirikan negara Islam atau penerapan syariat Islam, melainkan terlahir sebagai gerakan pembebasan negeri-negeri Muslim dari imperialis. ${ }^{15}$ Pada bagian akhir bukunya, Hanafi mengatakan bahwa dirinya merupakan bagian dari fundamentalisme Islam. Hanya saja, ia tidak masuk penjara atau mendapat siksaan fisik, karena dia melakukan aktivitas pemikiran dan politik secara natural dan terang-terangan, di atas bumi dan bukan di bawah tanah. ${ }^{16}$

Dengan fokus yang sama, yaitu gerakan fundamentalisme Islam di Mesir, A. Yani Anshori memfokuskan diri pada pengkajian historis tentang pembentukan ideologi gerakan fundamentalisme Islam. Menurutnya, pembentukan ideologi sekte ini lebih banyak dilakukan tokoh-tokoh sekte ini di balik jeruji besi. Ideologi ini kemudian menyebar ke hampir seluruh organisasi militan di Mesir. Dari Mesir inilah kemudian ideologi ini menyebar ke seluruh penjuru dunia Islam. ${ }^{17}$

15 Lihat Hassan Hanafi, Aku Bagian dari Fundamentalisme Islam, terj. Kamran As'ad Irsyady dan Mufliha Wijayati, (Yogyakarta: Islamika, 2003), h. 317-320.

16 Lihat bagian akhir buku tersebut, ibid.

17 A. Yani Anshori, "Ideologi dari Penjara: Dari Quthbism Menuju al-Qaidah," makalah dipresentasikan dalam Moslem Scholars Congress yang bertema "The Reading of The Religious Texts and The Roots of Fundamentalism," Saphir Yogyakarta, Minggu, 13 Juni 2004. 
Sementara Machasin, dalam makalahnya yang berjudul "Fundamentalisme dan Terorisme," menyatakan bahwa ada bagian-bagian dari teks-teks keagamaan dalam Islam yang memberikan ruang bagi aksi-aksi kekerasan atas nama agama. Teks-teks keagamaan tersebut dijadikan justifikasi bagi sekte fundamentalisme Islam untuk melakukan penyerangan-penyerangan dan ancaman terhadap eksistensi keberagamaan orang lain. Meski tentu cara pandang sekte fundamentalis Islam tersebut tidak dapat dibenarkan, namun ada beberapa hal yang oleh Machasin dianggap sebagai sesuatu yang positif dari sekte tersebut. Kelompok lain dapat mengambil beberapa pelajaran dari sikap dan kegiatan sekte fundamentalis Islam. Pertama, sekte fundamentalis memiliki loyalitas yang kuat pada keyakinan yang dianut. Kedua, sekte tersebut memiliki semangat kerja yang kuat. Ketiga, eksklusivitas sekte ini bisa dipergunakan untuk membangun kerja tim yang kuat. ${ }^{18}$

Sementara Dawam Rahardjo memandang bahwa terma fundamentalisme cukup sulit untuk digunakan dalam memahami fenomena Islam dan umat Islam. Karena terma tersebut memang sangat historis-spesifik, yaitu lahir dari gejala gerakan keagamaan Kristen Protestan di Amerika Serikat pasca Perang Dunia II. Nilai-nilai fundamental dalam ajaran Islam berbeda dengan "lima butir paham fundamentalisme" dalam ajaran gerakan Kristiani tersebut. Maka, demikian Dawam Rahardjo mengatakan, penggunaan istilah fundamentalisme memang harus disesuaikan dengan ajaran masing-masing agama dan latar belakang sosialnya. ${ }^{19}$

Yusril Ihza Mahendra, pakar hukum tata negara yang juga banyak mengamati fenomena fundamentalisme agama, memandang bahwa faktor kecenderungan dalam menafsirkan doktrin dan faktor-faktor politik, psikologis, sosial, budaya dan ekonomi merupakan faktor-faktor yang mempengaruhi kemunculan fundamentalisme. Ia lahir sebagai respon atas kondisikondisi lingkungan yang mempengaruhinya. Selama faktor lingkungan itu ada, maka selama itu pula kecenderungan munculnya fundamentalisme akan selalu ada, meski di masa mendatang mungkin akan mengambil bentukbentuk baru sesuai dengan tantangan yang muncul. ${ }^{20}$ Sedangkan Abegebriel

${ }^{18}$ Lihat Machasin, “Fundamentalisme dan Terorisme,”... h. 16.

${ }^{19}$ Lihat Dawam Rahardjo, Fundamentalisme, ... h. 93.

20 Yusril Ihza Mahendra, "Fundamentalisme, Faktor dan Masa Depannya," dalam Muhammad Wahyuni Nafis (ed.), Rekonstruksi dan Renungan Religius Islam, (Jakarta: Paramadina, 1996), h. 93. 
dan Nizar Ali lebih memfokuskan diri pada akar-akar kekerasan yang menurutnya banyak sekali ditemukan dalam hadits-hadits nabi. Hadits-hadits Nabi yang berbicara tentang kepemimpinan dan pemerintahan sering digunakan oleh kelompok fundamentalis Islam dalam melakukan aksi-aksi politiknya. ${ }^{21}$ Untuk membedakan itu, tulisan ini akan melakukan penelusuran terhadap ayat-ayat yang berpotensi melahirkan fundamentalisme Islam.

\section{Dinamika Konsep Fundamentalisme Agama}

\section{Konsep Fundamentalisme}

Fundamentalisme, diungkapkan dalam bahasa Arab dengan kata aluṣūliy dengan bentuk jamaknya al-ușūliyyūn yang berarti "sesuai dengan aturan, prinsip-prinsip dan kaidah." 22

Adapun awalnya, istilah fundamentalisme berasal dari umat Kristen Protestan di Amerika Serikat yang mempunyai makna berusaha kembali ke azas ajaran Kristen yang pertama. Azas mendasar tentang kitab suci yang diusung dalam fundamentalisme tersebut adalah: (1) Kitab suci secara harfiah tidak mengandung kesalahan (the literal inerrancy of the scriptures) (mengamankan kitab suci terhadap kritik kitab suci); (2) Kitab suci tidak dapat dipertentangkan dengan akal manusia; (3) Kitab suci (sacred text) tidak dipertentangkan dengan ilmu pengetahuan; (4) Mereka yang tidak sependapat dengan konsep tersebut dianggap Kristen yang tidak benar. ${ }^{23}$

Jika konsep tersebut diterapkan dalam Islam, maka hasilnya adalah: Pertama, sudah menjadi suatu kesepakatan dan pengakuan bahwa kitab suci (al-Qur'an) tidak mengandung kesalahan, sehingga dalam hal ini dapat dikatakan bahwa sikap orang Muslim terhadap teks al-Qur'an berprinsip fundamentalis. Namun isi teks al-Qur'an dapat dipahami melalui penafsiranpenafsiran dari para mufassir (dengan berbagai macam metode penafsirannya), baik secara harfiah maupun dengan pendekatan hermeneutika.

\footnotetext{
${ }^{21}$ Abegebriel dan Nizar Ali, "Fundamentalisme Hadits," makalah yang dipresentasikan dalam Moslem Scholars Congress" dengan tema "Reading of The Religious Texts and The Roots of Fundamentalism," Saphir Yogyakarta, Minggu, 13 Juni 2004.

22 Adib Bisri \& Munawwir AF, Kamus al-Bisri, (Surabaya: Pustaka Progresif, 1999), h. 75. 1993.

23 Djaka Soetapa, "Asal-usul Gerakan Fundamentalis," dalam Ulumul Qur'an, Vol. IV, No. 3,
} 
Kedua, mempertentangkan kitab suci dengan akal manusia, maka sejak awal justru Islam mendorong umatnya untuk merenungkan firman Allah dengan akal dan sekaligus memperhatikan alam ini sebagai tanda kekuasaannya. ${ }^{24}$

Ketiga, mempertentangkan kitab suci dengan ilmu pengetahuan, akal diberikan tempat dalam kesadaran beragama untuk menggali ilmu pengetahuan semaksimal mungkin untuk mencapai derajat manusia tertinggi. ${ }^{25}$ Apalai jika ilmu pengetahuan yang dipelajari justru ikut membantu dalam meningkatkan keimanan terhadap Allah, maka hal demikian justru diperintahkan. ${ }^{26}$

Keempat, jika seseorang yang tidak sependapat (seperti tawaran konsep di atas) dikatakan sebagai Islam yang tidak benar, merupakan sikap yang berlebihan karena Islam sendiri menghargai dan menghormati antar pemeluknya dalam mengamalkan ajarannya (sesuai dengan mazhabnya), sehingga paham inklusivisme intra-agama selalu hidup dalam masyarakat. Bukan hanya itu, bahkan Islam pun menghargai pemeluk agama lain. ${ }^{27}$.

Dalam kerangka beraktivitas, fundamentalisme juga mempunyai karakteristik tertentu yaitu: (1) Bersifat tertutup dan eksklusif; (2) Hidup menggerombol secara berkoloni, sebagai bias dari cara pandang mereka yang ekslusif; (3) Mempunyai pemikiran politik yang integralistik yaitu menyatukan antara agama dan kekuasaan; (4) Merancang perubahan radikal. ${ }^{28}$

Untuk mewujudkan rencana aktivitas tersebut, maka langkah yang diambil adalah menerapkan keputusan tanpa ada kompromi, semua pelakunya dituntun oleh yang mempunyai wewenang sebagai sumber otoritas transendental, mengupayakan tindakan politik dengan ideologi jihad dan amar ma'rūf nahi munkar dalam segala hal.

\section{Sejarah Fundamentalisme}

Fundamentalisme sebagai gejala politik keagamaan tidak lahir secara spontan, namun memiliki rentang waktu yang sangat panjang hingga istilah

${ }^{24}$ Lihat, QS. [2]: 76, [3]: 65, [4]: 84, [6]: 156, [7]: 57, [47]: 24.

${ }^{25}$ Lihat QS. [58]: 11.

${ }^{26}$ Budhy Munawar Rahman, Islam Pluralis, (Jakarta: Raja Grafindo Persada, 2004), h. 571.

${ }^{27}$ QS. al-Hajj [22]: 40.

${ }^{28}$ Richard T. Antoun, Memahami Fundamentalisme: Gerakan Islam, Kristen, Yahudi, (Surabaya: Pustaka Eurika), h. 7. 
tersebut dipakai dan digunakan bersanding dengan Islam. Secara makro, faktor yang melatarbelakangi lahirnya fundamentalisme adalah situasi politik, baik di tingkat domestik maupun tingkat internasional. Hal ini dapat dibuktikan dengan munculnya fundamentalisme pada masa akhir khalifah Ali bin Abi Thalib, di mana situasi politik tidak kondusif.

Diawali dengan kemelut politik sejak Ali diangkat menjadi khalifah, kemudian disusul dengan penolakan Mu'awiyah terhadap eksistensi kekhalifahan Ali, terjadilah ketegangan yang akut dari kedua belah pihak yang berujung terjadinya peristiwa "tahkim" antara Ali dan Mu'awiyah. Sebagian kelompok memihak Ali, sebagian yang lain memihak Mu'awiyah bahkan kelompok ketiga keluar dari keduanya dan melakukan oposisi yang akhirnya disebut dengan kelompok Khawarij. Kelompok ini memandang dirinya sebagai 'penengah' namun bersifat radikal.29 Sekte ini menggunakan pendekatan literalistik terhadap nash al-Qur'an tanpa memandang kemaslahatan manusia pada umumnya seperti ayat:

"Barang siapa yang tidak memutuskan hukum sesuai dengan ketetapan

Allah, mereka dianggap kafir." 30

Berawal dari munculnya sekte Khawarij sebagai gerakan laten fundamentalisme Islam di era khaliffah dengan pola pemikiran dan gerakannya, berlanjut hal yang serupa. Secara teoritik periode selanjutnya dapat digolongkan dalam dua periode yaitu periode pra-modern dan periode kontemporer. ${ }^{31}$ Fundamentalisme pra-modern muncul disebabkan situasi dan kondisi tertentu di kalangan umat Muslim sendiri, sedangkan fundamentalisme kontemporer bangkit sebagai reaksi terhadap penetrasi sistem dan nilai sosial, budaya, politik dan ekonomi Barat, baik sebagai akibat kontak langsung dengan Barat maupun melalui pemikir Muslim.

Fundamentalisme pra-modern muncul di Semenanjung Arabia di bawah pimpinan Muhammad bin Abdul Wahhab dengan kelompoknya yang disebut Wahhabisme. Fundamentalisme ini berkembang juga di berbagai belahan

${ }^{29}$ Khawarij berasal dari kata kharaja yang berarti keluar (keluar dari kelompok Ali). Sekte ini melakukan oposisi terhadap pemerintahan Ali maupun Muawiyah. Lihat Abu Zahrah, Tarikh Madzāhib al-Islāmiyyah, (Mesir: Dar al-Fikri al-Arabi, 1989), h. 60.

${ }^{30}$ QS. al-Maidah [5]: 44.

31 Hrair Dekmejian, Islam and Revolution; Fundamentalism in The Arab Word, (Syracuse: Syracuse University Press, 1985), h. 35. 
dunia Islam seperti di Nigeria Utara dengan tokohnya Syaikh Utsman dan Fodio-yang berhasil mendirikan kekhalifahan "Sakoto". Di wilayah Afrika Barat di bawah pimpinan Haji Umar Tal (1794-1865), di India dipelopori oleh Ahmad Syahid (1787-1831), selanjutnya menyebar ke Sinegal, Banglades serta Indonesia. ${ }^{32}$

Di Indonesia, fundamentalisme Islam disinyalir berkembang sekitar abad ke-17 dengan dua alasan yaitu: Yang pertama untuk memerangi adanya bid'ah dan khurafat agar kembali kepada Islam yang benar sebagaimana ajaran Wahhabi, hal ini ditandai dengan munculnya kelompok Padri di Minangkabau. Yang kedua karena kondisi sosial-politik serta ekonomi yang carut-marut, sedangkan pemerintah lamban dalam mengambil tindakan. Pada masa akhir pemerintahan Soeharto muncul fundamentalisme kontemporer karena saat itu Indonesia mengalami krisis multidimensi yang cukup hebat, adanya ketidakstabilan sosial-politik, ekonomi dan etika yang parah. Masyarakat menjadi resah serta kepercayaan terhadap pemerintah dan sistemnya menghilang, sebagaimana yang dialami oleh kelompok Khawarij pada masa awal kemunculannya.

\section{Landasan Teologi Fundamentalisme}

Fundamentalisme dianggap sebagai aliran yang berpegang teguh pada "fundament" agama Kristen melalui penafsiran terhadap kitab suci agama itu sendiri secara rigid dan literalis. Terlepas dari keberatan-keberatan yang dipahami, ide dasar dalam istilah fundamentalisme Islam terdapat kesamaan dengan fundamentalisme Kristen, yaitu kembali kepada fundamentals (dasardasar) agama secara "total" dan "literal," bebas dari kompromi, penjinakan dan reinterpretasi. ${ }^{33}$ Dalam ranah sejarah, fundamentalisme Islam berawal dari persoalan teologis, namun dalam perkembangannya lebih merupakan teori politik ketimbang teologi dan praktik sosial. Menurut kalangan fundamentalis, Islam bukan hanya diasumsikan sebagai alternatif ideologis, akan tetapi merupakan keharusan teologis dan politik secara bersamaan.

32 Maftuh Abegebriel, A, dkk., Negara Tuhan: The Thematic Encyclopaedia, (Jakarta: SR-Ins Publishing, 2004), h. 514.

33 Ernest Gelner, Post Modernism, Reasen and Religion, London, 1992, h. 2. 
Teori tersebut dikemas dalam "sistem Islam" yang menyeluruh, ideal dan modern dengan cara mengimplementasikan syariat Islam ke seluruh kehidupan pribadi maupun sosial sesuai dengan nash yang tersurat dalam alQur'an dan Hadits Nabi.

Dengan deskripsi tersebut, fenomena fundamentalisme dalam Islam dapat ditemukan pada dua akar teologi, yaitu pertama, merujuk pada gerakan yang memperjuangkan Islam sebagai entitas politik, asumsi ini diperkuat dengan latar sejarah Khawarij yang pada zamannya menempatkan hukum sebagai landasan politik. Kedua, merujuk pada generasi awal, yakni pada era kehidupan Nabi dan para sahabat—di mana saat itu orang Islam hidup secara sederhana dan agama dijalankan melalui prinsip-prinsip dasar Islam.

Untuk melanjutkan akivitasnya, di samping bersandar pada akar teologi juga menggunakan instrumen yang di sebut 'jihad'-yang diartikan dengan 'perang'. Konsep jihad ini sering kali dilegitimasi oleh kalangan Islam fundamentalis untuk melakukan tindakan teroris. Alasan yang mendasari berjihad secar teologis adalah sebuah ayat (QS. al-Baqarah [2]: 120) "Tidak akan rela baik Yahudi maupun Nasrani sehingga engkau tunduk kepadanya". Ayat ini dipahami bahwa orang Yahudi maupun Nasrani adalah pihak yang perlu diwaspadai karena selalu menyerang terutama terhadap akidah. ${ }^{34}$ Implikasi dari pemahaman yang literalistik ini dalam sejarah dapat dilihat ketika terjadi perang Salib antara umat Islam dan Kristen selama kurang lebih 300 tahun.

\section{Fundamentalisme Agama dalam al-Qur’an}

\section{Basic Text Fundamentalisme}

Al-Qur'an sebagai kitab suci, di dalamnya mengandung aturan berbagai dimensi kehidupan umat manusia-diantaranya mengatur sistem pemerintahan dan kenegaraan yang dalam pemahaman penafsiran al-Qur'an sebenarnya merupakan landasan teologi politik.

Konsep serta karakteristik fundamentalisme agama (Islam) pada dasarnya dapat dilihat pada pemahaman ayat-ayat tertentu yang menjadi dasar munculnya fundamentalisme Islam. Seperti dalam memahami ayat:

${ }^{34}$ Sayyid Quthb, Fi Zhilal al-Qur'an, Jill. I, terj. (Jakarta: Gema Insani Press, 2003), h. 195. 
"Pada hari ini telah Kusempurnakan bagimu agamamu dan telah Aku cukupkan kepadamu ni'mat-Ku, dan Aku ridhai Islam menjadi agamamu." 35

“Tidaklah kami alpakan sesuatu pun dalam al-Kitab." 36

"Kami turunkan kepadamu al-Qur'an sebagai penjelas sesuatu." 37

“Tidaklah patut bagi laki-laki dan perempuan mukmin, jika Allah dan rasul-Nya telah menetapkan ketetapan, mereka memilih jalan lain dalam urusannya. Barang siapa mendurhakai Allah dan Rasul-Nya mereka telah sesat." 38

Keempat ayat tersebut dipahami sebagai ayat yang menjadikan alQur'an sebuah kitab yang "komplit" (semua masalah sudah ada di dalamnya) dan bagi orang Muslim tidak dapat mengambil tindakan lain selain mengikuti naș tersebut apa adanya. Berawal dari pemahaman nash-nash tersebut dikembangkan pula konsep dalam kehidupan. Dalam konsep ideologi harus mengikuti Islam secara kaffah yang merujuk pada ayat:

"Hai orang-orang yang beriman, masuklah kedalam "Islam" seluruhnya dan jangan mengikuti langkah-langkah setan. Sesungguhnya setan merupakan musuh yang nyata." 39

Ayat ini mensuratkan wajib mengikuti manhaj rabbaniy secara total, mulai dari kehidupan pribadi seperti peribadatan sampai kehidupan sosial bernegara (termasuk bentuk kelembagaannya).40 Sedangkan dalam aktivitas perjuangannya para fundamentalis berpegang teguh pada ayat-ayat:

"Jika sudah habis bulan-bulan Haram, maka bunuhlah orang-orang musyrik itu di mana saja kamu jumpai, dan tangkaplah mereka, kepunglah mereka dan intailah di tempat pengintaian. Jika mereka bertobat, mendirikan shalat dan menunaikan zakat, maka berilah kebebasan untuk mereka." 41

Perintah memerangi ini disampaikan lagi dalam ayat 29:

"Perangilah orang-orang yang tidak beriman kepada Allah dan hari kemudian, dan tidak mengharamkan apa yang diharamkan Allah dan

\footnotetext{
${ }^{35}$ QS. al-Ma'idah [5]: 3.

${ }^{36}$ QS. al-An'am [6]: 38.

${ }^{37}$ QS. al-Nahl [16]: 89.

${ }^{38}$ QS. al-Ahzab [33]: 36.

${ }^{39}$ QS. al-Baqarah [2]: 208.

${ }^{40}$ Sayyid Quthb, Fi Zhilal al-Qur'an, h. 130.

${ }^{41}$ QS. al-Taubah [9]: 5.
} 
Rasul-Nya dan tidak beragama dengan agama yang benar, yaitu orang yang diberikan al-Kitab kepada meraka, sampai mereka membayar jizyah, sedangkan mereka dalam keadaan patuh dan tunduk." 42

Bahkan perintah tersebut dilegitimasi dalam QS. al-Anfal [8]: 61:

"Jika mereka condong kepada perdamaian, maka condonglah kepadanya dan tawakkallah lepada Allah."43

Ayat-ayat tersebut dipahami sebagai dasar untuk memerangi (memusuhi) orang-orang yang non Muslim, atau orang Islam yang tidak secara "total" menjalankan agama Islam. Bahkan ayat 61 QS. al-Anfal lebih memberikan dukungan, yaitu tidak boleh mengambil inisiatif berdamai kecuali jika mereka yang memulai terlebih dahulu. ${ }^{44}$

Masih ada ayat-ayat yang dijadikan dasar hukum dan politik: kedaulatan hukum berada di tangan Tuhan, ${ }^{45}$ konsep sosial: puritanisme dan keadilan sosial ${ }^{46}$ dan konsep teologi agama: eksklusivisme. ${ }^{47}$ Semua ayat-ayat tersebut mereka memahami secara literalis tanpa melihat pada aspek kesejarahannya maupun hermeneutiknya.

Melalui keyakinan yang skriptualis yakni keyakinan harfiah terhadap kitab suci sebagai firman Tuhan yang tanpa ada kesalahan, dikembangkanlah gagasan dasar yang dibingkai dalam kerangka metodologi (meminjam istilah Azyumardi Azra) yang mengandung prinsip: oposisionalisme, penolakan terhadap hermeneutika, penolakan terhadap pluralisme dan relativisme, serta penolakan terhadap perkembangan historis maupun sosiologis.

Dalam konsep dan karakteristik fundamentalisme agama (Islam) tersebut di atas, dapat dikatakan bahwa dasar sikap fundamentalisme Islam berasal dari nash al-Qur'an, akan tetapi hanya mengambil dan memahami ayat-ayatnya secara sepotong-sepotong. Tidak memahami ayat-ayat lain yang berhubungan dengan permasalah dan topik yang sama secara holistik-

42 QS. al-Taubah [9]: 29.

43 QS. al-Anfal [8]: 61. h. 17.

${ }^{44}$ Al-Qurthubi, al-Jamī’ li al-Ahkā̄m al-Qur'ān, Jil. 3-4, (Beirut: Dar al-Kutub al-'Alamiyah, 1993),

45 QS. al-Ma'idah [5]: 44, 45, 47.

${ }^{46} \mathrm{QS}$. al-Baqarah [2]: 228, 4: 34.

${ }^{47}$ QS. al-Baqarah [2]: 62. 
komprehensip, selain itu juga sering tidak mempertimbangkan latar belakang kesejarahan terhadap ayat-ayat yang dibaca dan dijadikan rujukan.

\section{Model Pemahaman}

Sesuai dengan azas fundamentalisme yaitu: "kembali kepada ajaran yang pertama” (al-Qur'an) mereka memahami nash al-Qur'an secara literalis (harfiah) sesuai dangan apa adanya yang tercantum dalam teks tersebut. Mereka tidak mau tahu apa sebenarnya tujuan al-Qur'an diturunkan untuk manusia melalui Muhammad, juga tidak melihat kembali bagaimana kondisi sosial (asbāb al-nuzūl) dari ayat-ayat tersebut. Banyak pendekatan yang dapat digunakan dalam memahami nash al-Qur'an, agar al-Qur'an benarbenar dapat membawa kemaslahatan umat.

Jika dilihat dengan teori kesejarahan maupun munāsabah dari ayat-ayat tersebut diatas maka dalam QS. al-Taubah [9]: 5, suruhan membunuh pada ayat tersebut bukan berarti perintah wajib akan tetapi hanya izin untuk membunuh, begitu juga menangkap dan menawan. Alasan pendapat ini karena suruhan membunuh itu datang setelah ada larangan (yaitu dilarang membunuh pada bulan haram), maka bentuk perintah seperti ini tidak punya nilai "wajib". Kecuali jika mereka memang sangat membahayakan dan cenderung tidak bertobat.

Sedangkan ayat 29, menurut riwayat adalah ayat yang pertama kali turun berkenaan dengan perang terhadap Ahli Kitab (musyrik), karena ada sekelompok Nasrani yang merasa khawatir terhadap ajaran Muhammad, lalu mereka mengumpulkan pasukan dari suku Arab yang beragama Kristen dan bergabung dengan kekuasaan Romawi untuk menyerang kaum Muslim, sehingga orang Muslim merasa cemas terlebih setelah mereka mendengar bahwa pasukan sudah sampai di dekat Yordania. Kecemasan kaum Muslim tersebut dijawab oleh Allah dengan menurunkan ayat tersebut. ${ }^{48}$

Adapun QS. al-Anfal [8]: 61 adalah sebagai anjuran sikap orang Muslim ketika diajak berdamai. Ayat ini berhubungan dengan ayat sebelumnya yang menceritakan sikap orang musyrik yang selalu memusuhi orang Muslim yang seakan orang Muslim merasa takut jika suatu saat orang Musyrik mengajak berdamai. Perasaan takut ditepis oleh ayat tersebut karena takut hanya boleh

${ }^{48}$ Quraish Shihab, Tafsir al-Misbah, (Jakarta: Lentera Hati, 2002), Juz. 5, h. 573-574. 
kepada Allah, bukan dipahami sebaliknya (baru mau berdamai ketika meraka yang memulai). Perdamaian adalah dambaan setiap manusia, selama perdamaian itu adil, maka tidak ada halangan bagi kaum Muslim untuk menerima perdamaian, bahkan dianjurkan menawarkan perdamaian selama ada kemaslahatan..$^{49}$ Bahkan hal ini juga tidak sesuai dengan konsep al-Qur'an yang melarang saling bermusuhan, membenci atau berprasangka buruk. ${ }^{50}$ Pendapat al-Qurthubi yang melarang perdamaian tersebut dapat diterima dalam kondisi tertentu seperti pada masa peperangan. Oleh karena itu secara metodologis, fundamentalisme agama (Islam) hanya melihat nash (baik alQur'an maupun Hadits) pada tataran harfiahnya saja dan memahami ayat secara satu persatu atau sepotong-sepotong.

Al-Qur'an merupakan kitab universal, maka ayat-ayatnya harus dipahami secara holistik-komprehensif tidak diambil secara sepotong-sepotong. Maka ditawarkan pendekatan pemahaman dengan cara munāsabah antar ayat, pendekatan lain yang ditawarkan adalah dengan melihat latar belakang kesejarahan (sabab nuzūl) terhadap turunnya aya-ayat tertentu. Oleh karena itu dengan teori-teori tersebut diharapkan al-Qur'an akan menjadi "kitab rujukan" di semua tempat dan sepanjang waktu untuk mencapai kedamaian dan kemaslahatan. Sehingga pada akhirnya al-Qur'an akan menjadi raḥmatan li 'l-āallamìn sepanjang masa.

\section{E. Kesimpulan}

Dari uraian penulis, dapat dicapai beberapa poin penting. Pertama, fundamentalisme yang pada awalnya berasal dari agama Kristen di Amerika dengan azasnya yang 'keras' diadopsi oleh agama-agama lain termasuk Islam dengan azas dan karakter yang 'serupa' walau tidak sama persis. Kedua, fundamentalisme pada mulanya muncul akibat masalah teologi namun selanjutnya berkembang sejalan dengan perkembangan politik ketimbang masalah teologi. Ketiga, dalam rentang sejarah fundamentalisme Islam merujuk pada masa khalifah Ali bin Abi Thalib dengan munculnya sekte Khawarij yang berwatak 'keras' sebagai akibat ketidakpercayaan sekelompok masyarakat terhadap kebijaksanaan pemerintah.

${ }^{49}$ Wahbah al-Zuhaili, Tafsìr al-Munïr, juz. 7-8, h. 87.

${ }^{50}$ QS. al-Hujurat [49]: 11-12. 
Keempat, untuk melegitimasi keberadaannya, fundamentalisme Islam bersandar pada ayat-ayat al-Qur'an yang dianggap 'tepat', mayoritas ayat yang digunakan sebagai dasar adalah ayat-ayat yang bernada 'keras' dan 'kaku'. Kelima, metodologi penafsiran yang digunakan untuk memahami ayat-ayat tersebut adalah pemahaman secara literalistik seperti yang tertera dalam bunyi ayat tanpa memandang apa dan bagaimana tujuan dari ayat-ayat tersebut diturunkan. Serta terakhir, dalam pemahamannya juga ayat-ayat al-Qur'an hanya dipahami secara sepotong-sepotong tanpa memandang ayat yang lain, atau dalam istilah lain tidak memandang ayat al-Qur'an secara holistik-komprehensif yang menjadikan al-Qur'an sebuah kitab yang universal.[w] 


\section{BIBLIOGRAFI}

Abegerbriel dan Nizar Ali, "Fundamentalisme Hadits," makalah yang dipresentasikan dalam Moslem Scholars Congress dengan tema "Reading of The Religious Texts and The Roots of Fundamentalism," Hotel Saphir Yogyakarta, Minggu, 13 Juni 2004.

Ali, Atabik \& Zuhdi Muhdlor, A, Kamus Kontemporer Arab-Indonesia, Yogakarta: Multi Karya Grafika, Pondok Krapyak, 2003.

Anshori, A. Yani, Ideologi dari Penjara: dari Quthbism Menuju al-Qaidah, makalah dipresentasikan dalam Moslem Scholars Congress yang bertemakan "The Reading of The Religious Texts and The Roots of Fundamentalism," Hotel Saphir Yogyakarta, Minggu, 13 Juni 2004.

Antoun, Richard C., Memahami Fundamentalisme, terj. Muhammad Shodiq, Surabaya: Pustaka Eureka, 2003.

Asfahani, Al-Raghib al, Mu'jam al-Mufradat al-Fadz al-Qur'an, Beirut: Dar al-Fikri, t.th.

Ayubi, Nazih, Political Islam: Religion and Politics in the Arab Word, London: Routledge, 1991.

Azra, Azyumardi, "Fenomena Fundamentalisme dalam Islam," dalam Ulumul Qur'an, Vol.IV, No. 3, 1993.

"Memahami Gejala Fundamentalisme," http://media.inset.org/islam/ Etc/Gejala.html, diakses 19 Juni 2008.

Binder, Leonard, Islam Liberal Kritik terhadap Ideologi-Ideologi Pembangunan, Terj., Imam Muttaqin, Yogyakarta: Pustaka Pelajar, 2001.

Bisri , Adib \& Munawwir AF, Kamus al-Bisri, Surabaya: Pustaka Progresif, 1999.

Bukhary, Muhammad Ibn Ismail al, Șahīh al-Bukhäry, Bandung: Syirkah al-Ma'arif, t.th.

Danny, Fredrick M., Islam and the Moslem Community, New York: Herper Row, 1987. 
Dekmejian, Hrair, Islam and Revolution: Fundamentalism in the Arab Word, Syracuse: Syracuse University Press, 1985.

Depag RI, al-Qur'an dan Terjemehannya, Jakarta: Restu Bumi, 1990.

Efendi, Bachtiar \& Hendro Prasetyo (peny), Radikalisme Agama, Jakarta: PPIMIAIN, 1993.

Enayat, Hamid, Moden Islamic Political Thogh; the Response of the Syili and Sunni Moslim's to the Twentiets Centur, London: The MacMilland Press Ltd, 1992.

Fadl, Khaled Abu El, Cita dan Fakta Toleransi Islam, terj. Heru Prasetyo, Bandung: Arasyi, 2003.

Faris, Ibnu, Mu'jam al-Maqayis fi I-Lughah, Beirut: Dar al-Fikr, 1994.

Gelner, Ernest, Post Modernism, Reasen and Religion, London, 1992.

Ghazali, Jawāhir al-Qur'ān, Beirut: Dar al-Afaq al-Jadidah, 1983.

Hanafi, Hassan, Aku Bagian dari Fundamentalisme Islam, terj. Kamran As'ad Irsyady dan Mufliha Wijayati, Yogyakarta: Islamika, 2003.

"Asal-Usul Konservatisme Keagamaan dan Fundamentalisme Islam," dalam Ulumul Qur'an, No. 7, Vol. II, 1990.

http://www.tranungkite.net/lama/b12/ap92.htm, Kamis, 19 Juni 2008.

Huntington, Samuel P. , "The Clash of Civilization” dalam Foreign Affairs, Vol. 72, 1993.

Katsir, Abi Fida' Ismail Ibn, Tafsïr Ibn Katsïr, Beirut:Dar al-Fikr, t.th.

Katsir, Ibnu, Tafsīr al-Qur'ān al-'Aẓim, Juz. II, Beirut: Dar al-Ma'rifat, t.th.

Khalaf, Abd. Wahhab, 'Ilm al-Fiqh, Kairo: Dar al-Qalam, 1978.

Lewis, Bernard, The Political Language of Islam, Chicago: University of Chicago Press, 1988.

Machasin, "Fundamentalisme dan Terorisme," makalah yang dipresentasikan dalam Moslem Scholars Congress dengan tema "Reading of The Religious Texts and The Roots of Fundamentalism," Hotel Saphir Yogyakarta, MInggu, 13 Juni 2004.

Mahendra, Yusril Ihza, "Fundamentalisme, Faktor dan Masa Depannya," dalam Muhammad Wahyuni Nafis (ed.), Rekonstruksi dan Renungan Religius Islam, Jakarta: Paramadina, 1996.

Walisongo, Volume 20, Nomor 1, Mei 2012 
Marty, Martin E. "What is Fundamentalism? Teological Perspective," in Hums Kung \& Jurgan Moltman (ed.), Fundamentalist as a Ecumanical Callange, London: 1992.

Massignon, Louis, Al-Hallaj: Sang Sufi Syahid, terj. Dewi Candaningrum, Yogyakarta: Fajar Pustaka Baru, 2001.

McMullan, Harry, "Understanding Christian Funda-mentalism," http://www. ubfellowship.org/archive/ readers/doc176. htm.

Moghissi, Haideh, Feminisme dan Fundamentalisme Islam, terj., Maufur, M, Yogyakarta: LKIS, 2005.

Poerwadarminta, WJS, Kamus Besar Bahasa Indonesia, Jakarta: Balai Pustaka, 1990.

Qublan, Hisam, Ma'a al-Qur'ān fi 'l-Dīn wa'l-Dunyā, Beirut: Manshurat-Uwidat, 1986.

Qurthubi, al, al-Jāmi' li 'l-Ahkām al-Qur'ān, Jl. 3-4, Beirut: Dar al-Kutub al-'Alawiyah, 1993.

Qutb, Sayyid, Fi Zhilal al-Qur'an, Juz. I, V, Jakarta: Gema Insani Press, 2003.

Rachman, Budhy Munawar, Islam Pluralis, Jakarta: Raja Grafindo Husada, 2004.

Rahardjo, M Dawam, "Fundamentalisme" dalam Muhammad Wahyuni Nafis (ed.), Rekonstruksi dan Renungan Religius Islam, Jakarta: Paramadina, 1996.

Rahman, Fazlur, "Islam Challenges and Opportunities" dalam Alford T. Welch \& Piere (peny), Islam: Past Influence and Present Challenge, London: Edinburg University Press, 1979.

Raziq, Ali Abd., al-Islām wa Ușūl al-Hukm, Beirut, 1996.

Ridha, Rasyid, Tafsìr al-Manār, Juz IV, Beirut: Dar al-Ma'rifat, tth.

Soetapa, Djaka, “Asal-usul Gerakan Fundamentalisme” dalam Ulumul Qur'an, No. 3 Vol. IV, 1993.

Sulaiman, Abu Dawud, Sunan Abi Dāwūd, Riyadh: Maktabah Dahlan, t.th.

Suyuti, As, Lubāb al-Nuqūl fi Asbāb al-Nuzūl, Riyadh: Maktabah Riyadh alHaritsah, t.th.

Syahrastani, Al, al-Milāl wa'l-Nihāl, Juz. I, Beirut: Dar al-Marifat, 1975. 
Syarkun, Muchlas \& W. Ghorara, "Dunia Islam dalam Benturan Kepentingan dan Peradaban" dalam Maftuh Abegebriel A, dkk,, Negara Tuhan: The Thematic Encyclopaedia, Jakarta: SR. Ins Publishing, 2004.

Shihab, M. Quraish, Wawasan al-Qur'an: Tafsir Tematik atas Pelbagai Persoalan Umat, Bandung, Mizan, 2007. Tafsir al-Misbah, Jl. I, V, Jakarta: Lentera Hati, 2006.

Tibbi, Bassam, Ancaman Fundamentalisme, terj. Imran Rasyidi, Yogyakarta: Tiara Wacana, 2000.

The Challenge of Fundementalism: Political Islam and The New Word Disorder, California: University of California, 1998.

Wetch, Al-Ford T. \& Piera Chacia (ed.), Islam Past Influence and Present Challenge, Endinburgh: Endinburgh University, 1979.

Zahrah, Abu, Tarikh Madzāhib al-Islāmiyyah, Mesir: Dar al-Fikr al- Arabi, 1989.

Zamakhsyari, Tafsir al-Kashshaf'an Haqāiqq al-Tanzïl, Juz. I, Beirut: Dar al-Ma'rifat, t.th. 
